\title{
Diurnal Cycle of Heating and Water Vapor in the Metropolitan Area of Porto in Portugal
}

\author{
Hugo Abi Karam ${ }^{1}$ (), Jorge Fernando Soares Gonçalves ${ }^{2}$ (), Augusto José Pereira Filho ${ }^{3}$ (i) \\ ${ }^{1}$ Departamento de Meteorologia, Instituto de Geociências, Universidade Federal do Rio de Janeiro (IGEO-UFRJ), \\ Rio de Janeiro, Brazil \\ ${ }^{2}$ IBERMETEO, Coimbra, Portugal \\ ${ }^{3}$ Departamento de Ciências Atmosféricas, Instituto de Astronomia, Geofísica e Ciências Atmosféricas, Universidade de São Paulo \\ (IAG-USP), São Paulo, Brazil \\ Email: hugo@igeo.ufrj.br, jorge.goncalves@ibermeteo.com, augusto.pereira@iag.usp.br
}

How to cite this paper: Karam, H.A., Gonçalves, J.F.S. and Filho, A.J.P. (2022) Diurnal Cycle of Heating and Water Vapor in the Metropolitan Area of Porto in Portugal. Journal of Geographic Information System, 14, 61-77.

https://doi.org/10.4236/jgis.2022.141004

Received: January 23, 2022

Accepted: February 22, 2022

Published: February 25, 2022

Copyright $\odot 2022$ by author(s) and Scientific Research Publishing Inc. This work is licensed under the Creative Commons Attribution International License (CC BY 4.0).

http://creativecommons.org/licenses/by/4.0/

(c) (i) Open Access

\begin{abstract}
In this work, it is investigated the Urban Heat Island (UHI) using conservative thermodynamic variables observed by surface weather stations on the Metropolitan Area of Porto (Oporto) in Portugal, under adiabatic conditions at the surface. These conditions are usually present and associated with the development of a mixture layer into the diurnal Convective Boundary Layer (CBL), which residual layer in the late afternoon defines the initial state for the development of the nocturnal UHI. Both the spatial structure and temporal variation of potential temperature and specific humidity were considered, along the hours and days of the year, from a statistical point of view, resulting in hourly climatology. Details of the hourly evolution of the meteorological variables on the Oporto surface are presented and discussed. Results show a seasonal variation of the potential temperature up to $17^{\circ} \mathrm{C}$ throughout the year, which is associated with horizontal thermal gradients that can control and trigger mesoscale circulations such as sea-land, urban and valley-mountain breezes.
\end{abstract}

\section{Keywords}

Metropolitan Area of Porto (Oporto) Climatology, Urban Heat Island

Development, Urban Boundary Layer, Mesoscale Atmospheric Circulations

\section{Introduction}

The total population of the world increased substantially in the last few decades [1]. For instance, the urban population of Europe corresponds to $72 \%$ or about $18 \%$ of the world's urban population. A 2030 scenario indicates an increase of 
the urban population to $78 \%$ and a reduction to $11 \%$ of the rural population. Eventually, the urban population dwelling will be more dependent on job opportunities, services, infrastructure, and mobility, in a scenario of climatic change.

Urban areas have distinctive specific energy and water budgets tied to Urban Heat Island (UHI) effects such as lower specific humidity, higher air temperature, and precipitation, so that some mesoscale features are very important to understand atmospheric circulation in cities [2].

The Urban Heat Island also induces higher water and electrical energy consumption and a greater number of infrastructural and health hazards, particularly in association with heat waves occurrences such as that of 2003 in Europe. Indeed, local climate variability in cities and global changes require multidisciplinary studies in urban dwellings and time work schedule beyond increase of urban greening actions to mitigate not wanted urban heat island effects [3].

Oporto has 1.7 million inhabitants over an area of $1883 \mathrm{~km}^{2} ; 888$ people $\mathrm{km}^{-2}$. Porto city is a major urban center with one of the highest population densities in Europe with 6400 people $\mathrm{km}^{-2}$. About 264 thousand people live in an urban area on the northern slope and plateau of $41 \mathrm{~km}^{2}$ on the Douro river valley with its highest altitude at $155 \mathrm{~m}$ above sea level ${ }^{[4]}$.

Some previous studies carried out for Porto City and Southern Portugal [5] [6] [7] [8] [9] focused on precipitation distribution and variability caused by surface winds, sea surface temperature (SST) along the coast of Southern Portugal, the North Atlantic Oscillation (NAO) and its bio-climatic classification [10] [11]. El Niño-Southern Oscillation (ENSO) and NAO have been studied as players in the Iberian Peninsula climate variability [12] [13] [14] [15] [16].

Heatwaves in Europe including Portugal are frequent. The relationship between atmospheric circulation, Sea Surface Temperature (SST), precipitation, and heatwave events over Western Europe have been investigated, as well the effect of extremely high temperatures on daily mortality rates in Lisbon and Madrid [17] [18]. A Watch Warning Surveillance System was built and updated for monitoring heat waves with potential impacts on morbidity and mortality, and a new approach to improve quantifying impacts of heat waves on mortality rates [19] [20].

The main features of Lisbon Urban Heat Island have been studied using a step-wise multiple regression and obtained a $2.5^{\circ} \mathrm{C}$ difference value [21]. Another investigation has found temperature differences up to $7^{\circ} \mathrm{C}$ due to the Oporto Urban Heat Island [22]. Additionally, the diurnal cycle of air pollutants and concentrations of $\mathrm{CO}, \mathrm{O}_{3}, \mathrm{NOx}$, and PM10 also has been carried out for the Oporto [23].

There are few published studies on the Oporto Urban Heat Island. Some researches point out that the Oporto Urban Heat Island is associated with the development of an Urban Boundary Layer (UBL) in a temperate climate zone. By hypothesis, the circulation cell generated by the Oporto Urban Heat Island can be coupled to the circulation cell of the sea-land breeze (SB) under favorable 
conditions. The coupling of the Oporto Urban Heat Island circulation with the $\mathrm{SB}$ circulation can occur in the absence of more intense synoptic flows (i.e., external forcing), for example, like those resulting from the movement of cold and warm fronts.

The interaction between the Oporto Urban Heat Island and SB circulations may be associated with the formation of storms over the urban conurbation or neighborhoods. These are theoretical aspects that can be better addressed from data analysis such as the one presented in this work. Observations and investigations of this type of UHI iterations exist for the Metropolitan Region of São Paulo (MASP) and the Metropolitan Region of Rio de Janeiro (MARJ) [24] [25] [26].

Noteworthy is the fact that the maximum intensity of the Urban Heat Island of the MASP and MARJ occurs in the afternoon and the morning, respectively, therefore in phase with the period of greatest heating of the surfaces by the density flux of solar radiation [27]. It is observed that the maximum of the MASP Urban Heat Island occurs almost synchronously with the entrance of the sea breeze, which brings relatively humid air with a lower temperature that advances over the urban conurbation of the MASP from Southeast to Northwest, in favorable feedback to the development of storms of greater vertical development over the city, so that it rains heavily on the city and not on the water sources that are located in the mountains to the north of the conurbation. Naturally, this has consequences for the availability of rain to recharge water sources, which can lead to a risk of shortages of drinking water in drier years (such as 2014) and erosion processes [28] [29].

Observational work and numerical modeling with mesoscale models for storm simulation show that these iterations are intense enough to intensify the vertical movement within the storms, thus generating severe storms, with hail and intense precipitation [30] [31].

Added to the higher urban temperature associated with the Oporto Urban Heat Island, the lower branch of the shallow circulation cell of the sea breeze that advects humid air over the urban area can reinforce the necessary conditions for the development of more intense storms (i.e., from a theoretical point of view). Studies by the Oporto Urban Heat Island are required to confirm these hypotheses.

Note the relevance of investigating the effects of the Oporto Urban Heat Island, given the increasing urbanization, the potential loss of thermal and environmental comfort, the worsening of the dangers associated with heat waves added to the higher temperatures of the urban surface and the increase in the frequency of severe storms under conditions of increased surface heating. Therefore, there is a need to investigate the hydrometeorological hazards associated not only with present and future global warming due to climate change (associated with the anthropogenic emission of greenhouse gases) but also due to surface land modifications. Urbanization is able to modify the energy and surface water balance [32] [33] [34] [35] [36]. 
In this way, carrying out systematic investigations on the Oporto Urban Heat Island can lead to a better understanding of the kinematics and dynamics of the Urban Heat Island itself and its interrelationships with the formation of intense storms, local and regional water availability, management of hydrometeorological hazards and epidemics, especially those associated with high temperatures such as the Dengue infectious disease, air pollution, hospitalizations, mortality. These issues have been evaluated by different researches, e.g., [37] [38] [39].

In this work, Oporto Urban Heat Island is analyzed using air potential temperature and air specific humidity under dry and adiabatic conditions. Database of automatic weather stations (AWS) mesonetwork is used to characterize the urban micro-climate of Oporto.

The need to investigate diurnal weather cycles in the Oporto originates from the fact that complex interactions in the Oporto Urban Heat Island often result from which interactions between mesoscale and synoptic weather processes. The joint analysis of diurnal and seasonal cycles of atmospheric variables has received increasing attention in the literature as data of higher sampling frequency (i.e., mesoscale) became available [40]. The main research purpose of this work is to show the importance of diurnal and seasonal variations in understanding the evolution of thermodynamic conservative variables during the Oporto Urban Heat Island evolution, evidencing the iterations between sea-land breeze and urban breeze cells associated with the development of the Oporto Urban Heat Island at diurnal and seasonal scales.

\section{Methodology and Data}

\subsection{Conservative Thermodynamic Variables}

The thermodynamics of the conservative variables under adiabatic conditions (for dry air) applied in this work were calculated using known from the atmospheric thermodynamic [41] [42].

\subsection{Sazonal Surface Water Balance of Oporto}

According to Köppen-Geiger's climate classification (KGCC), Oporto has a subtropical climate Csb, of dry summer or the Mediterranean [42]. It is typical of western continental areas between latitudes $30^{\circ}$ and $45^{\circ} \mathrm{N}$ [43] [44].

The monthly averages of temperature $\mathrm{T}$ in $\left({ }^{\circ} \mathrm{C}\right)$ and precipitation $\mathrm{P}$ in $(\mathrm{mm})$ for the city of Porto-PT, obtained from measurements in the period 1971-2000 [45] are shown in Figure 1. The temperature for summer varies between $10^{\circ} \mathrm{C}$ and $22^{\circ} \mathrm{C}$ and in winter between $0^{\circ} \mathrm{C}$ and $18^{\circ} \mathrm{C}$. In the summer, precipitation accumulation is smaller than $40 \mathrm{~mm}$ and in the winter it increases up to 200 $\mathrm{mm}$.

Oporto has a hot and dry summer due to the dominance of the subtropical high-pressure system. Oporto is located on the Northern coast of Portugal, being the Atlantic Ocean surface influenced by cold currents, associated with the frequency of fog occurrences. 


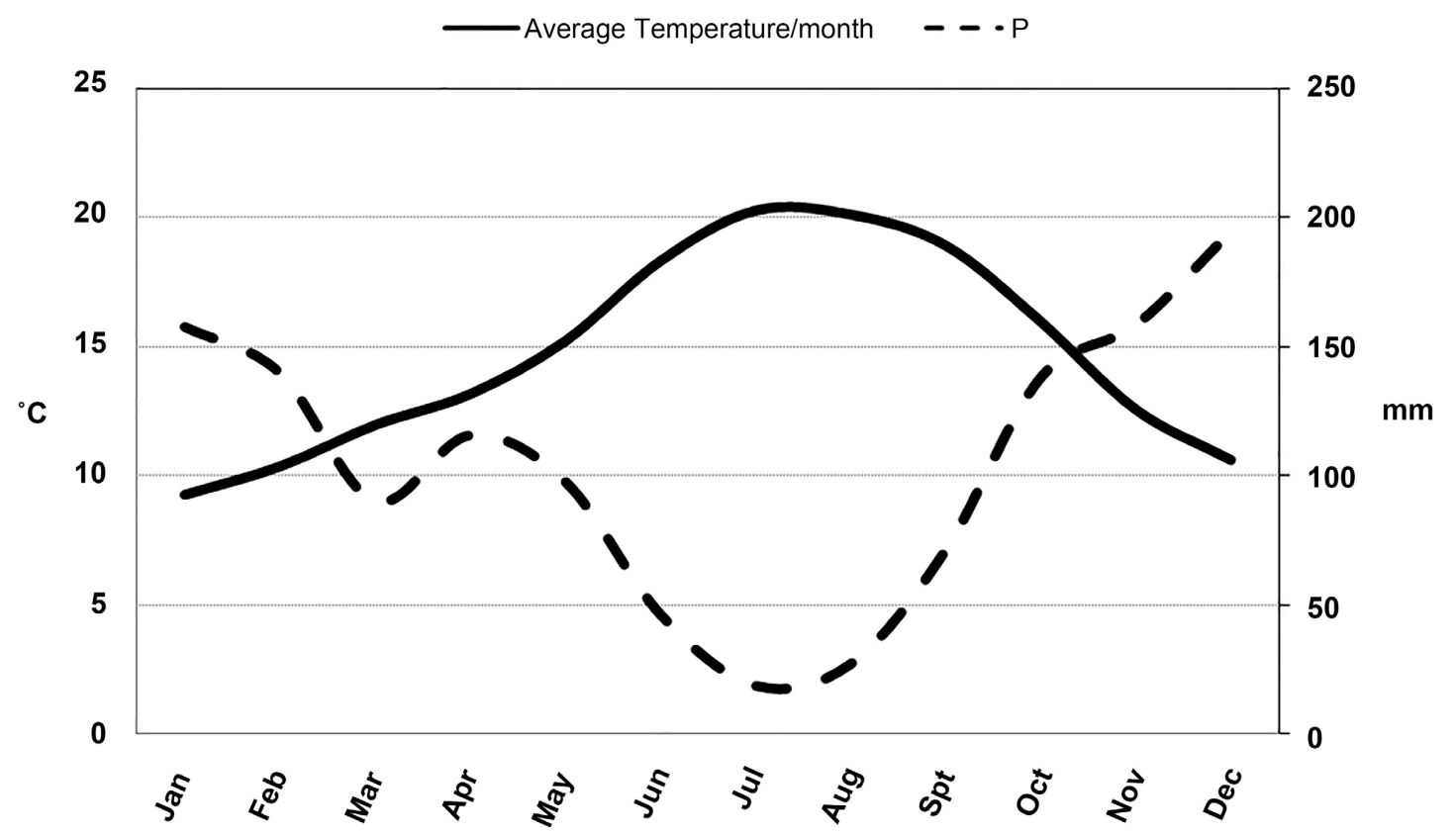

Figure 1. Evolution of the monthly average of the temperature $\left({ }^{\circ} \mathrm{C}\right)$ and precipitation $(\mathrm{mm})$ for Porto-PT, shown by continuous and dashed lines, respectively. Data source: [45].

The monthly average of the Surface Water Balance (SWB) [46] [47] can be written as

$$
\mathrm{P}-\mathrm{S}-\mathrm{E}-\mathrm{Q}=0
$$

where $\mathrm{P}$ is the precipitation rate; $\mathrm{S} \sim 0.05 \mathrm{P}$ is the approximate infiltration rate responsible for the ground storage, $\mathrm{E} \sim 0.167 \mathrm{ETP}$ represents the actual evaporation obtained as a function of the potential evapotranspiration (ETP) and Q is the surface runoff Here these fluxes are expressed in units of $\left(\mathrm{mm} \mathrm{month}{ }^{-1}\right)$.

The monthly averaged surface water budget components for Oporto are presented in Figure 2. Precipitation (P) and surface runoff $(\mathrm{Q})$ present almost the same magnitude because Oporto city surface is can be considered as being an impermeable surface due to the paved surface and small amount of surface vegetated in bare soil. Evaporation is higher during the hot and dry summer months, being modulated by the entry of the sea breeze of the Atlantic Ocean.

\subsection{Study Area and Surface Weather Data}

The study area in the center-north of Portugal includes the city of Porto and parts of the conurbations of Aveiro and Viseu. The geographic location of the network of surface weather stations (AWS) is shown by white stars in Figure 3. Available data between 1996-2009 were obtained concentrating data from the mirror Wunderground [48], reformatted to obtain with variables in columns and the sample time in rows.

The resulting file to each station presents a similar structure, which was employed in the analysis and comparisons. Unpaired data were excluded and the arithmetic averages and standard deviations were used for neglecting data with 


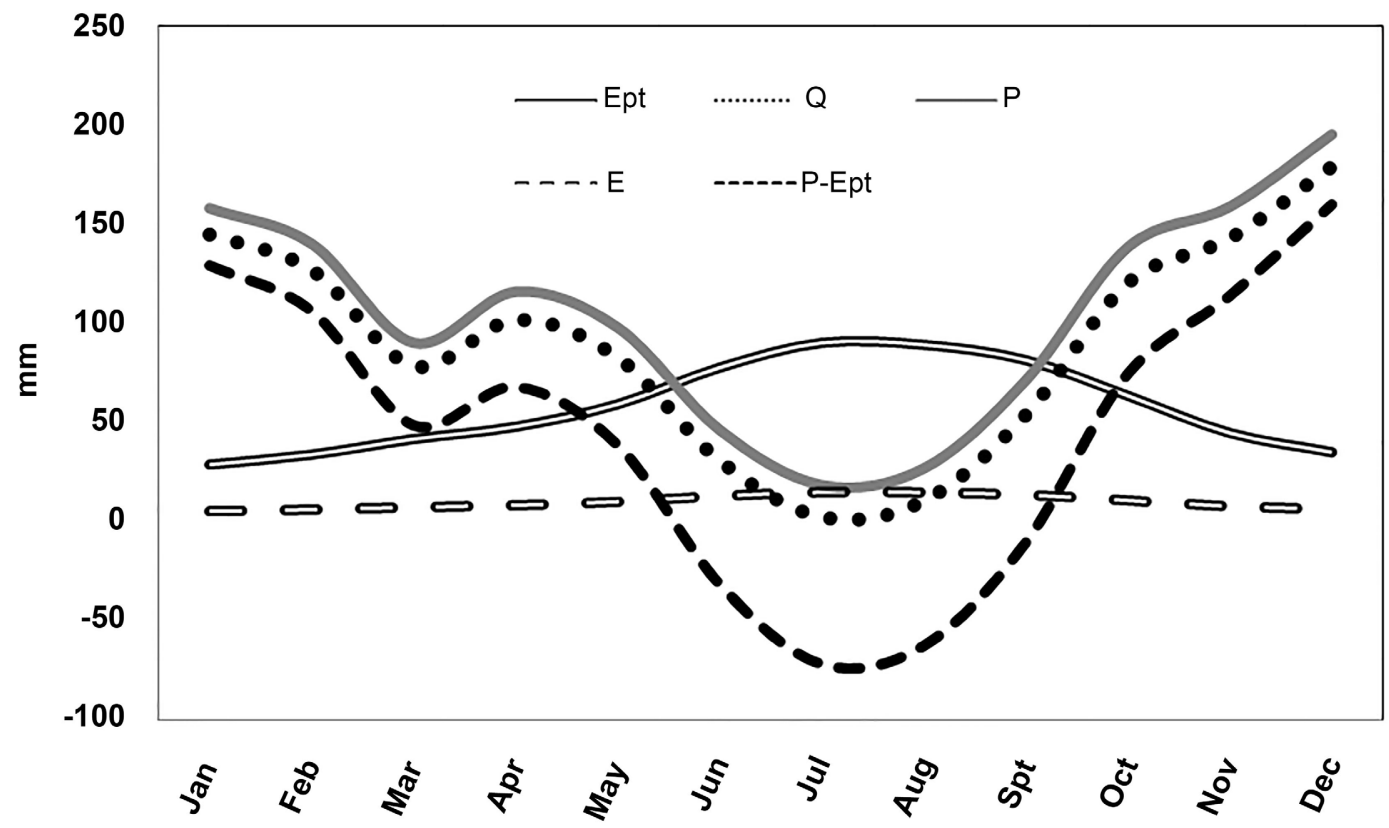

Figure 2. Monthly evolution of the average surface water balance for Oporto-PT. The Key indicates the estimated values: potential evapotranspiration (EPT), precipitation $(\mathrm{P})$, potential water availability $(\mathrm{P}-\mathrm{Ept})$, surface runoff $(\mathrm{Q})$, and real evapotranspiration (E). Analysis: this work.

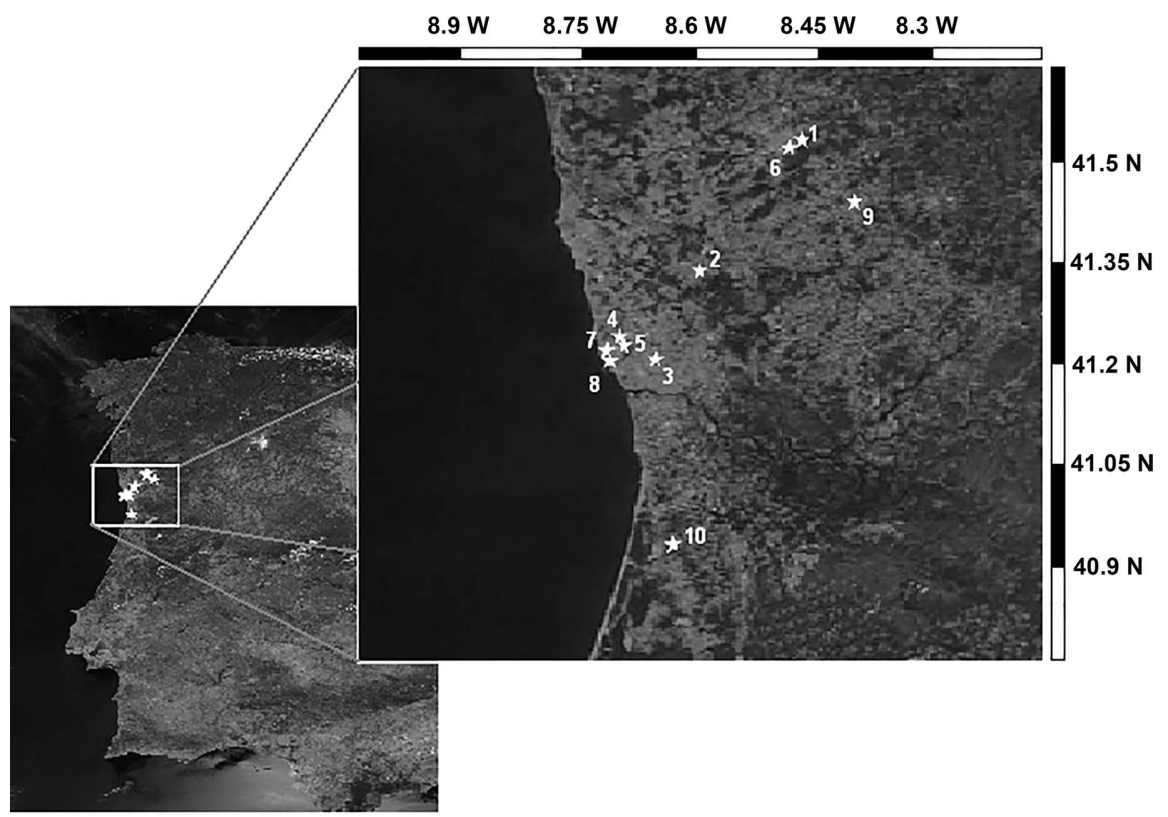

Figure 3. OPorto area (square symbol in the left side of the figure) and the location of the weather stations in this area, indicated by numbers and stars (in the right side of the figure). Key: (1) Braga; (2) Trofa; (3) Montes Burgos; (4) Pedras Rubras; (5) LPPR International Airport; (6) Farm of Chapel (Braga); (7) Leça da Palmeira; (8) Leça da Palmeira (Sardoal); (9) Guimarães; (10) Arada (Ovar).

large deviations from the mean (i.e., deviations bigger than two standard deviations). Following the equations proposed by Bolton [41], the development of conservative thermodynamic variables, for each day in the year and hour in the 
day, can be obtained and hourly values computed.

\section{Results}

\subsection{The UHI and Thermal Atmospheric Circulation}

The analysis of the micro-climates occurrences of Oporto was accomplished with temporal sections of conservative variables for adiabatic conditions along the year and hour of the day.

The LPPR AWS was used as a reference station because it presents the most complete dataset. This station is near to the international airport Francisco Sá Carneiro (longitude $41^{\circ} 13^{\prime} 47.89^{\prime \prime} \mathrm{N}$; latitude $8^{\circ} 40^{\prime} 47.90^{\prime \prime} \mathrm{W}$ ) at $64 \mathrm{~m}$ altitude (AMSL). The analysis of the variables for the LPPR station is shown in the present subsection. The statistical analysis was based on deviation fields is presented in the following subsection.

The surface air temperature presents similar characteristics to the potential temperature (Figure 4(a)). Since the surface air pressure is slightly higher than the reference air pressure $\left(\mathrm{p}_{0}\right)$, the potential temperature is slightly smaller than the corresponding air temperature. The potential temperature variation during the summer is consistent with the solar radiation cycles (figure not shown), with variation between $7^{\circ} \mathrm{C}$ and $12^{\circ} \mathrm{C}$ in the winter, and $20^{\circ} \mathrm{C}$ to $25^{\circ} \mathrm{C}$ in the summer.

The surface air pressure, with a maximum during the winter $(1020$ - 1023 $\mathrm{hPa}$ ) and almost constant on the rest of the year (1015 - $1018 \mathrm{hPa}$ ) (Figure 4(b)). High-pressure systems due to cold air masses in winter can cool the land surface faster than the ocean water surface. Fast warming of the surface in summer lowers surface air pressure conform the warm air ascends and produces surface convergence of the airflow. On the other hand, under dry conditions, convective rainfall is not frequent, but precipitation can occur when there is a low-pressure system centered over southern Iceland.

The specific humidity varies from $5 \mathrm{~g} \cdot \mathrm{kg}^{-1}$ in winter up to $12 \mathrm{~g} \cdot \mathrm{kg}^{-1}$ in summer (Figure $4(\mathrm{c})$ ). Therefore, this variation in the surface water vapor content is responsible for the observed variations of the dew point temperature. The relative humidity (HR) (Figure 4(d)) is higher at night in summer (96\%), mainly due to the decrease in the air temperature. On the other hand, $\mathrm{RH}$ is relatively lower (60\%) during the afternoons. Air temperature decreases to a value near to the dew point temperature during the afternoons and evenings. A surface thermal inversion can yield a stable layer (i.e., the stable boundary layer) associated with fog conditions.

The equivalent potential temperature shows a strong seasonal oscillation from $20^{\circ} \mathrm{C}$ in winter to $60^{\circ} \mathrm{C}$ in summer (Figure $4(e)$ ). It is an indication of hot and dry summers and rainy winters. The Oporto $\mathrm{HR}$ and the associated equivalent potential temperature $\left(\theta_{e}\right)$, a conservative variable under pseudo adiabatic conditions, are correlated in Oporto for both adiabatic and saturated conditions. High values of $\theta_{e}$ indicate the air parcel really must ascend more to reach the saturation condition (i.e., due to the adiabatic cooling). The surface HR is maximum 

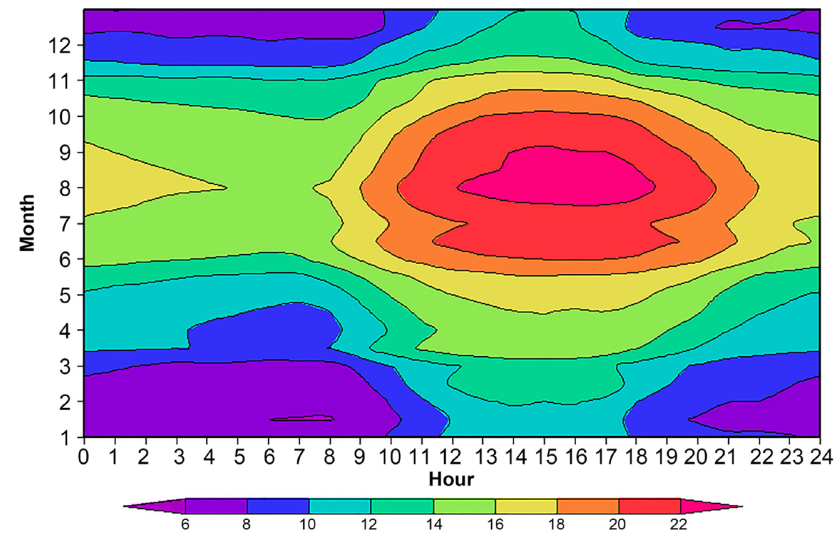
GrADS: COLAIGES

(a)

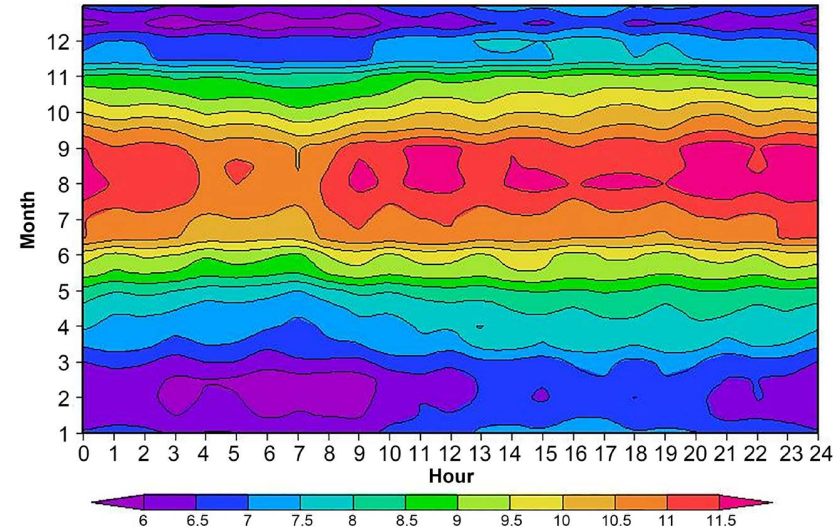

(c)

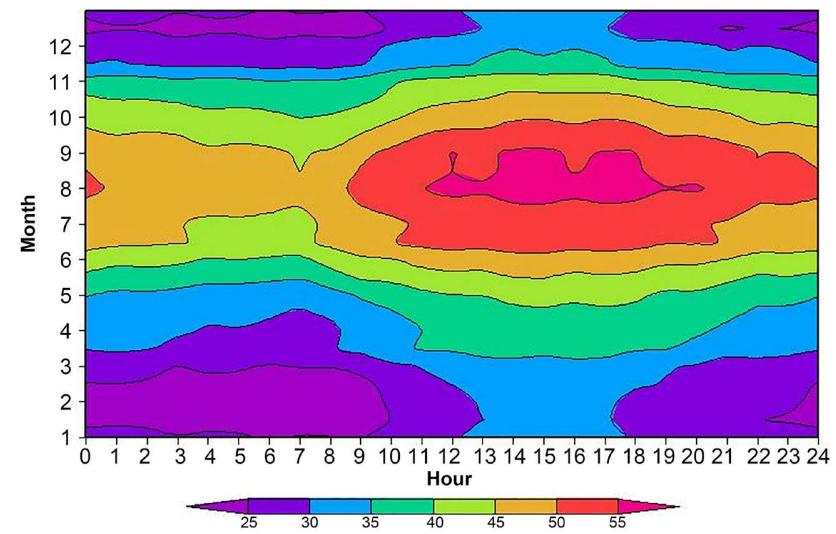

(e)

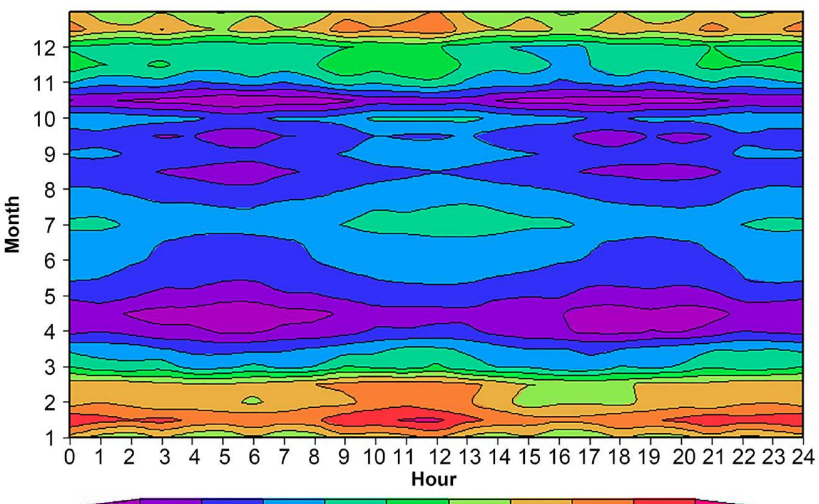

$\begin{array}{llllllllll}1015 & 1016 & 1017 & 1018 & 1019 & 1020 & 1021 & 1022 & 1023 & 1024\end{array}$

(b)

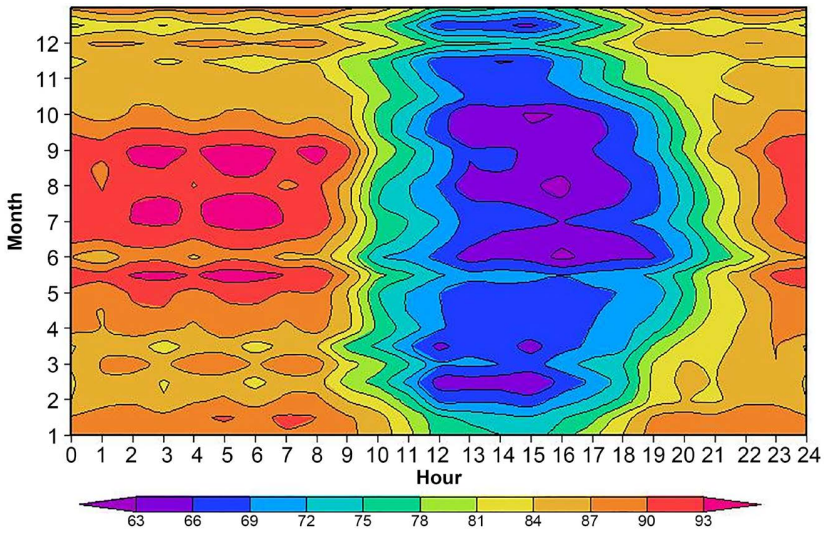

(d)

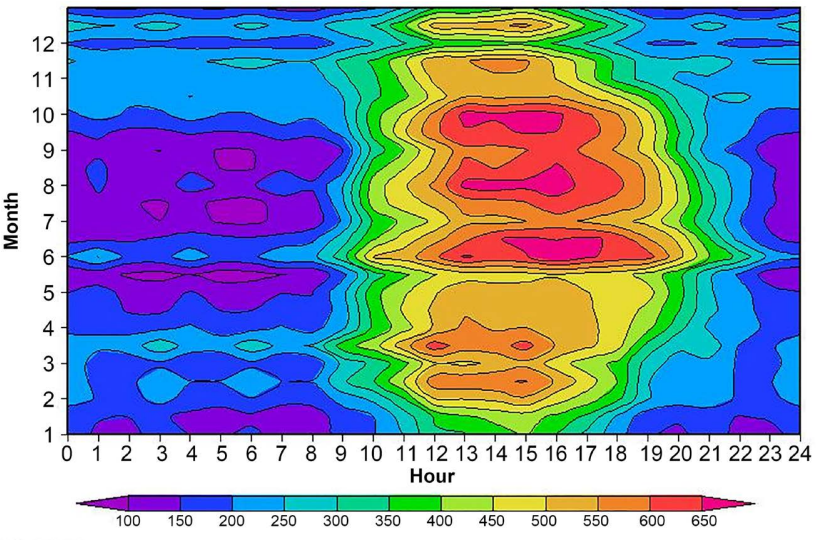

(f)

Figure 4. Seasonal and diurnal cycle of measured meteorological variables for Oporto from 1996 to 2009: (a) potential temperature $\theta\left({ }^{\circ} \mathrm{C}\right)$; (b) surface air pressure $\mathrm{P}(\mathrm{hPa})$; (c) specifics humidity q $\left(\mathrm{g} \cdot \mathrm{kg}^{-1}\right)$; (d) relative humidity HR (\%); (e) equivalent potential temperature $\theta_{e}\left({ }^{\circ} \mathrm{C}\right) ;(\mathrm{f})$ and lift condensation level LCL $(\mathrm{m})$.

in the afternoons of August (60\%), which implies an increase in the frequency of the convective rainfall in this month.

The evolution of the lift condensation level (LCL) in Oporto inversely proportional to HR is presented in Figure 4(f). Late afternoon shows a height between 
$450 \mathrm{~m}$ and $650 \mathrm{~m}$, and at night between $100 \mathrm{~m}$ and $200 \mathrm{~m}$. The variations are as diurnal development of the atmospheric boundary layer, with the feature being a convective boundary layer (CBL) during the day and stable (SL) along the night. High solar radiation in the early afternoon further increases the height of the mixed layer in the CBL. Thus, the boundary-layer turbulence is efficient in mixing the water vapor from the surface into the mixing layer. At the same time, produces entrainment of relatively cool and dry air from the free atmosphere into the inside of the CBL, increasing the LCL height.

The wind field presents a major feature, which is the sea-land breeze, modulated by the seasons and presence of sloped terrain from west to east (Figure 5). In winter months the land breeze is prevailing during mornings and nights, associated with a thermal gradient, with negative signal, from the east for the west. In summer, and particularly in the afternoons, it is observed the circulation of the sea-land breeze, then associated with the reversion of the thermal gradient, now positive, from the east for the west. This positive gradient is increased due to the coupling of the sea-land breeze circulation with the valley-mountain circulation, being this last can be associated with the baroclinicity of the sloped terrain in mesoscale, elevating from the west for east. The temperature gradient is likely associated with the difference in the thermal capacity of the surfaces.

The wind direction is also influenced by the orientation of the coastline SWNE. An almost constant phase of the sea breeze circulation is observed, from the morning (i.e., $1100 \mathrm{LT}$ ) to the end of the afternoon, with an intensification of the wind speed, which is likely a consequence of the increase of the surface temperature, particularly between March and October. A direct circulation intensity is proportional to the module of the horizontal thermal gradient, which implies

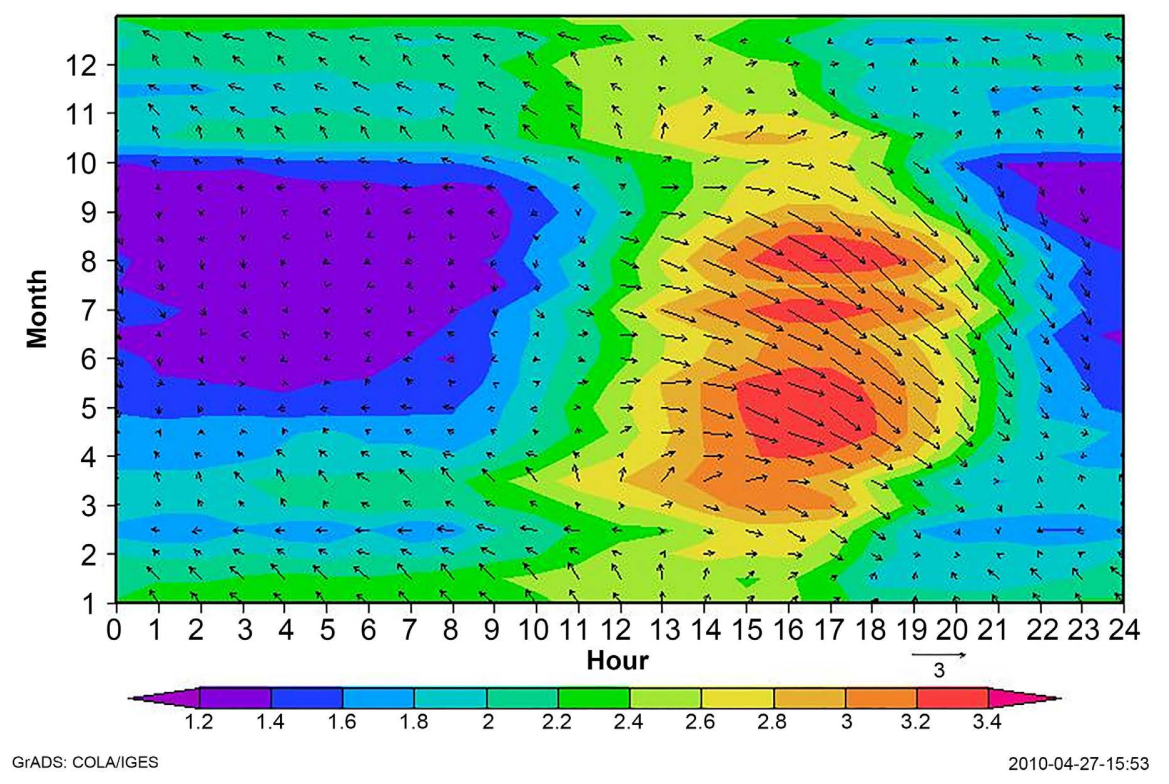

Figure 5. Climatology of the seasonal and diurnal cycle of the surface vector wind velocity for Oporto between 1996 and 2009. Colors indicate wind speed $\left(\mathrm{m} \cdot \mathrm{s}^{-1}\right)$ and vectors, the horizontal wind direction. 
the maximum wind speed of $3 \mathrm{~m} \cdot \mathrm{s}^{-1}$ from NW in the afternoon and $1.5 \mathrm{~m} \cdot \mathrm{s}^{-1} \mathrm{SE}$ in the night.

\subsection{Temporal Variability of the UHI of OPorto}

In this subsection, the spatial variations of conservative variables are analyzed by comparing the time series of the network of AWS on OPorto, namely, potential temperature and relative humidity fields. The results for all AWS are compared. The AWS sites were separated using the annual average of the potential temperature (Figure 4) and the cross-correlation between each station and the LPPR station to the micro-climates discriminated due to the changes in surface use (e.g., urban to the rural area).

The discrimination criteria were defined by the simultaneous occurrence of $\left\|<\theta>-\left\langle\theta_{\mathrm{LPPR}}\right\rangle\right\| 2^{\circ} \mathrm{C}$ and $\mathrm{R}^{2}>0.95$, where $\langle\theta>$ is the annual average of the potential temperature, for any weather station in the network, $R^{2}$ is the coefficient of determination and $\left\langle\theta_{\mathrm{LPPR}}\right\rangle$ is the corresponding value for the reference station LPPR (Table 1). The AWS network was divided into just two groups of stations: group $\mathrm{G}_{1}=\{\mathrm{LPPR}, 2,3,4,7$, and 8$\}$ and group $\mathrm{G}_{2}=\{1,6,9$, and 10$\}$. Figure 6 shows the average diurnal cycles for each AWS. The maximum potential temperature in group $\mathrm{G}_{2}$ (group $\left.\mathrm{G}_{1}\right)$ is $22^{\circ} \mathrm{C}\left(18^{\circ} \mathrm{C}\right)$ in the afternoons.

The stations of $G_{2}$ have greater thermal amplitudes since they are further inland, where the sky view parameter is larger, which increases the shortwave incoming radiance flux during the day, as also the outgoing of thermal long-wave radiance along the night, under conditions of clear sky (i.e., in comparison with the shadows and the trapping long-wave radiance into urban canyons). Differences of 90 minutes of the phase of the thermal wave of groups $G_{1}$ and $G_{2}$ were observed, likely due to the large distance to the coast of group $\mathrm{G}_{2}$.

Figure 7 shows the seasonal and diurnal cycles of $\theta$ (left column) and HR

Table 1. Average potential temperature $\langle\theta\rangle$ in $\left({ }^{\circ} \mathrm{C}\right)$ for each of the stations, the average thermal difference $\|<\theta\rangle-\left\langle\theta_{\mathrm{LPPR}}\right\rangle \|$ in $\left({ }^{\circ} \mathrm{C}\right)$, and the coefficient of determination $\left(\mathrm{R}^{2}\right)$ about the reference station (LPPR).

\begin{tabular}{cccc}
\hline AWS & $\langle\theta\rangle$ & $\left\|\langle\theta\rangle-\left\langle\theta_{\text {IPPR }}\right\rangle\right\|$ & $\mathbf{R}^{2}$ \\
\hline 1 & 15.69 & 2.13 & 0.965 \\
2 & 14.26 & 0.70 & 0.996 \\
3 & 14.40 & 0.84 & 0.968 \\
4 & 13.48 & 0.08 & 0.999 \\
\hline LPR & 13.56 & 0 & 1 \\
\hline 6 & 16.68 & 3.12 & 0.997 \\
7 & 15.45 & 1.88 & 0.977 \\
8 & 13.76 & 0.20 & 0.986 \\
9 & 16.14 & 2.58 & 0.976 \\
10 & 14.92 & 1.36 & 0.903 \\
\hline
\end{tabular}


(right column). Two well-defined seasons are evident: one relatively warm between June and September and a cold and rainy season between December and February. The relative humidity decreases in summer down to $60 \%$ (weather station $\mathrm{G}_{1}$ ) and $35 \%$ (for station $\mathrm{G}_{2}$ ) during the afternoons. The result indicates that the HR amplitude in spring (March to May) is higher than in autumn (October to November).

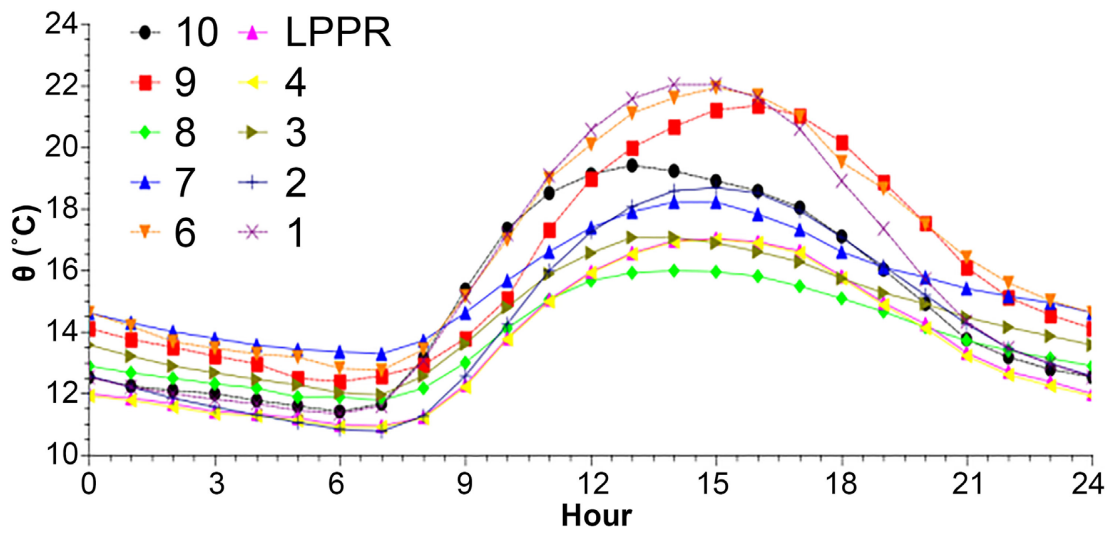

Figure 6. Diurnal evolution of the average potential temperature $\theta\left({ }^{\circ} \mathrm{C}\right)$ between 1996 and 2009 as a function of the hour, for each AWS, as indicated in by the labels.

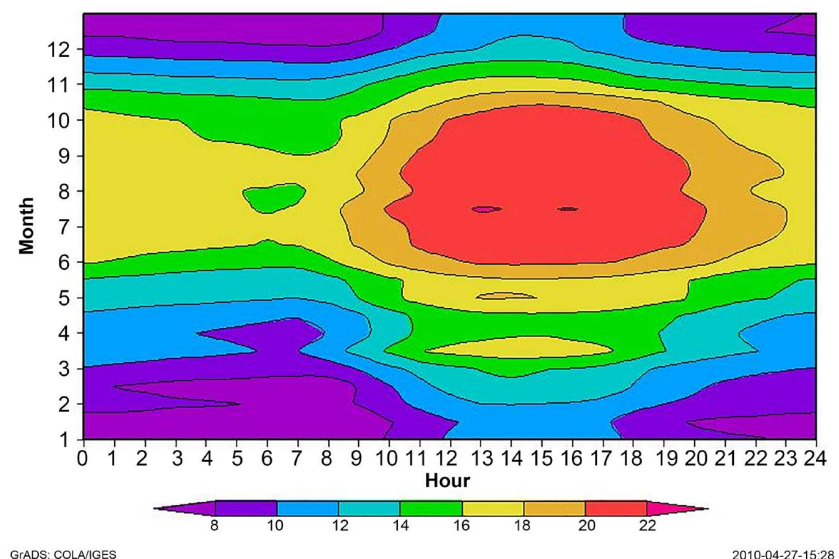

(a)

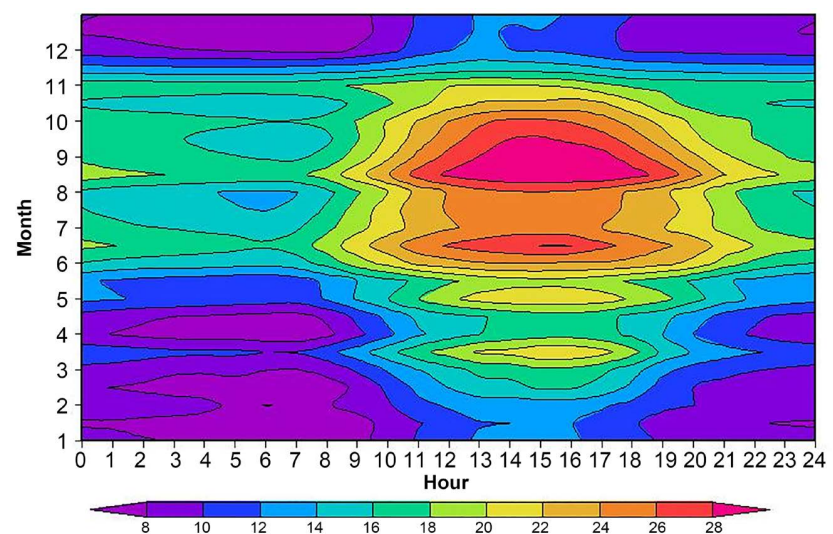

(c)
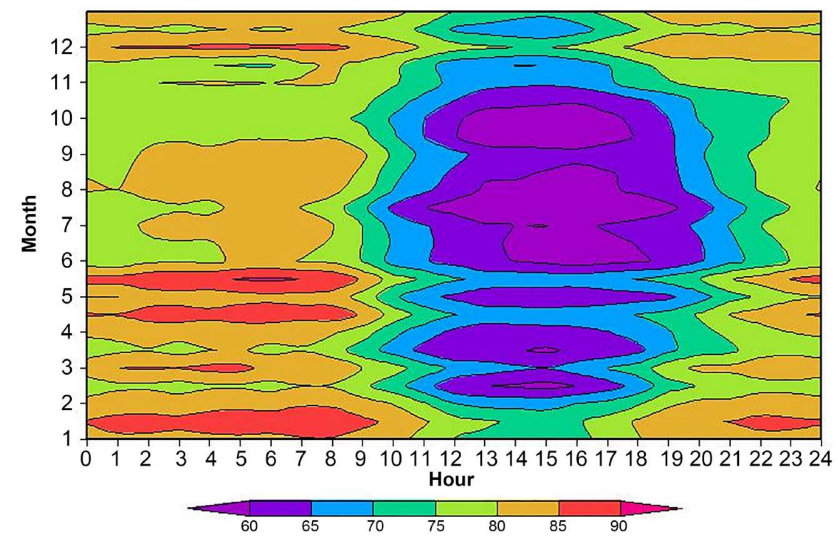

(b)

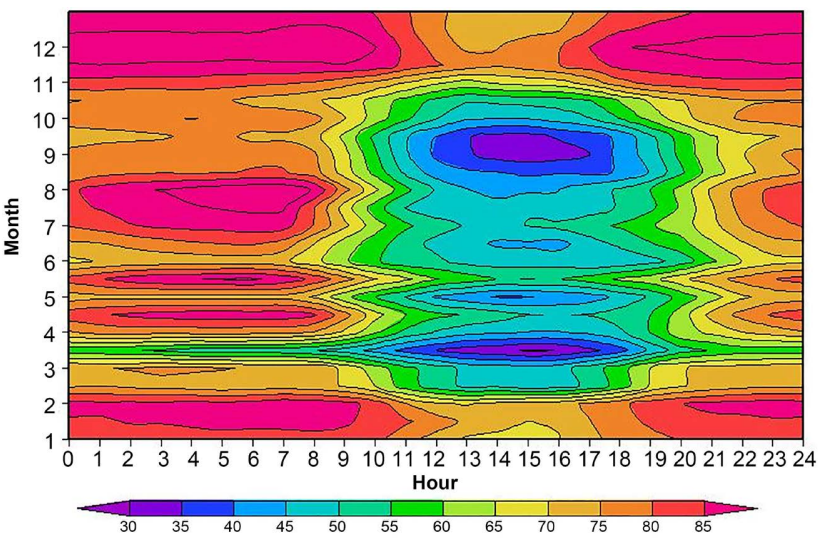

(d) 


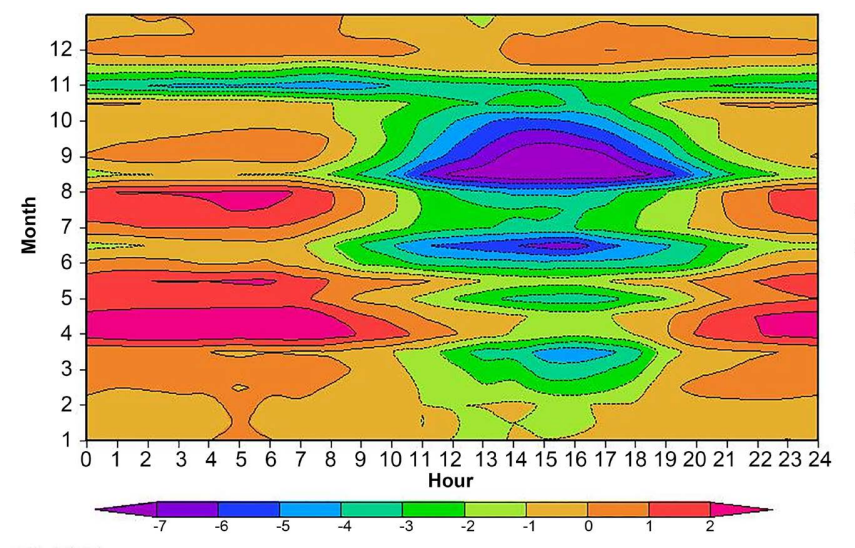

(e)

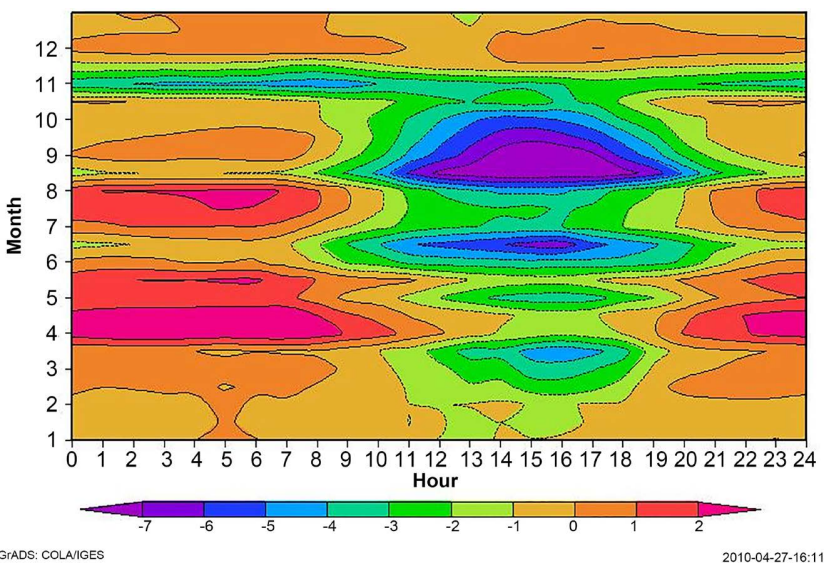

(f)

Figure 7. Diurnal (x-axis) and seasonal (y-axis) mean cycles of the potential temperature (left column) and the relative humidity (right column) for AWS group $G_{1}(a, b)$ and group $G_{2}(c, d)$. The difference between the groups $\left(G_{1}-G_{2}\right)$ is shown in (e, f).

The diurnal cycle of potential temperature $\theta$ is forced by the net radiance density flux $\left(R_{n}\right)$, which usually works as the major heat source at the surface. Observations of components of surface radiation balance are not available in the available data. The thermal amplitude reaches $4^{\circ} \mathrm{C}$ for $\mathrm{G}_{1}$ and $12^{\circ} \mathrm{C}$ for $\mathrm{G}_{2}$. The amplitude and the phase of the diurnal cycle of $\theta$ seem to be conditioned by the NW-SE orientation of the sea-land breeze circulation at the surface. The relative humidity shows values higher at night time and decreases to their minimum at near $1500 \mathrm{LT}$. The diurnal variation of HR in $\mathrm{G}_{2}$ is systematically higher than in group $\mathrm{G}_{1}$, being $45 \%$ for $\mathrm{G}_{1}$ and $20 \%$ for $\mathrm{G}_{2}$.

The UHI is commonly computed considering a) the spatial distribution of air temperature inside and outside of the urbanized area, or b) using just two characteristic weather stations, one for each land cover. However, three characteristic surfaces are present in Oporto: 1) sea surface, 2) urban surface, and 3) rural surface. On the other hand, the UHI of Oporto is also affected by this spatial distribution of surface sensible heat fluxes $(\mathrm{H})$.

Theoretically, the heterogeneous distribution of $\mathrm{H}$ can create a UHI in a form of a dome over the city. Consequently, the urban breeze circulation can be formed and to couple with other mesoscale circulations present over there. Therefore, the circulation dynamics can be associated with the thermodynamic process. The sea breeze brings relatively dense, wet, and cold maritime air over the land surface, initially warm and dry, decreasing $\theta$ and increasing $\mathrm{HR}_{\text {in }} \mathrm{G}_{1}$.

The existence of a horizontal thermal gradient between the groups is analyzed based on the diurnal evolution of the average potential temperature $\theta\left({ }^{\circ} \mathrm{C}\right)$ for each AWS. At $0400 \mathrm{LT}$, the thermal gradient is from $\mathrm{G}_{2}$ to $\mathrm{G}_{1}$, with a maximum intensity of $2^{\circ} \mathrm{C}$ in $40 \mathrm{~km}$ from April to August and less in the other months. HR differences are small but in July is $10 \%$. During afternoons (1500 LT), the $\theta$ structure is $7^{\circ} \mathrm{C}$ smaller and HR is $25 \%$ greater. Thus, $G_{1}$ is colder. In afternoons, Oporto presents better thermal comfort than further inland, but is subject to intense heat spells, as the one observed in 2003. 
The spatial distribution of the potential temperature can be associated with thermal horizontal gradients. In the winter afternoons, it is observed a negative gradient of approximately $-20^{\circ} \mathrm{C}$ by $100 \mathrm{~km}$, associated with larger SST about the continental surface temperature. Later spring and in the summer (i.e., from April to August), just before sunrise (0400 LT), there is a positive gradient of approximately $5^{\circ} \mathrm{C}$ by $100 \mathrm{~km}$, associated with the presence of the nocturnal UHI of Oporto and also of a smaller SST.

\section{Conclusion}

The main features of the Oporto Urban Heat Island were characterized by the potential temperature and relative humidity that have been analyzed between 1996 and 2009. Oporto results suggest hot and dry summer with temperatures between $17^{\circ} \mathrm{C}$ and $25^{\circ} \mathrm{C}$ and rainy winter with a mean temperature variation from $6^{\circ} \mathrm{C}$ to $10^{\circ} \mathrm{C}$. Fog conditions were observed during summer mornings. The prevailing wind is from the southeast during the winter nights and mornings, from the northwest during summer afternoons. The maximum wind speed is 3 $\mathrm{m} \cdot \mathrm{s}^{-1}$ and is related to the local sea breeze circulation. Potential temperature difference reached $17^{\circ} \mathrm{C}$ links to air mass sources effects. Two main thermal gradients were found during the year, the first from east to west of about $0.2^{\circ} \mathrm{C} \mathrm{km}^{-1}$ in summer afternoons, and a second one from west to east of $0.05^{\circ} \mathrm{C} \mathrm{km}^{-1}$ at 0400 LT between April and August. The analysis has shown the relevance of both the diurnal and seasonal cycles of thermodynamic variables to a better understanding of the Oporto micro-climates. Therefore, the results presented had shown the importance of diurnal and seasonal variation in understanding the behavior of the Oporto Urban Boundary Layer associated with the mesoscale sea-land thermal and humidity contrast, development of breeze circulation cells and Oporto Urban Heat Island at both diurnal and seasonal scales.

\section{Acknowledgements}

Thanks to Dr. Alfredo Rocha (UA-Portugal) and Dr. Edson P. Marques Filho (UFBA, Brazil) and for their comments that enriched the initial version of the manuscript. We also express thanks to the Instituto de Geosciences (IGEOCCMN-UFRJ) and the support from CNPq. A.J.P.F is sponsored by Conselho Nacional de Desenvolvimento Científico e Tecnológico (CNPq) under grant 302349/2017-6.

\section{Conflicts of Interest}

The authors declare no conflicts of interest regarding the publication of this paper.

\section{References}

[1] IPCC (2007) Climate Change Impacts, Adaptation, and Vulnerability. Contribution of Working Group II to the Fourth Assessment Report of the Intergovernmental 
Panel on Climate Change. Cambridge University Press, Cambridge, 976 p.

[2] Oke, T.R. (1987) Boundary Layer Climates. 2nd Edition, Methuen \& Co., London, $435 \mathrm{p}$.

[3] Masson, V., Marchadiera, C., Adolphe, L., Aguejdad, R., Avner, P., Bonhomme, M., Bretagne, G., Briottet, X., Bueno, B., de Munck, C., Doukari, O., Hallegatte, S., Hidalgo, J., Houet, T., Le Bras, J., Lemonsu, A., Long, N., Moine, M.-P., Morel, T., Nolorgues, L., Pigeon, G., Salagnac, J.-L., Viguié, V. and Zibouche, K. (2014) Adapting Cities to Climate Change, a Systemic Modelling Approach. Urban Climate, 10, 407-429. https://doi.org/10.1016/j.uclim.2014.03.004

[4] I.N.E. (2008) Instituto Nacional de Estatística, Portugal. Territorial Data of the Metropolitan Area of Porto. http://www.ine.pt

[5] Lemos, R.T., Sansó, B. and Santos, F.D. (2009) Hierarchical Bayesian Modeling of Wind and Sea Surface Temperature from the Portuguese Coast. International Journal of Climatology, 30, 1423-1430. https://doi.org/10.1002/joc.1981

[6] Costa, A.C. and Soares, A. (2009) Trends in Extreme Precipitation Indices Derived from a Daily Rainfall Database for the South of Portugal. International Journal of Climatology, 29, 1956-1975. https://doi.org/10.1002/joc.1834

[7] Santos, J.A., Andrade, C., Corte-Real, J. and Leite, S. (2009) The Role of Large-Scale Eddies in the Occurrence of Winter Precipitation Deficits in Portugal. International Journal of Climatology, 29, 1493-1507. https://doi.org/10.1002/joc.1818

[8] Fragoso, M. and Gomes, P.T. (2008) Classification of Daily Abundant Rainfall Patterns and Associated Large Scale Atmospheric Circulation Types in Southern Portugal. International Journal of Climatology, 28, 537-544.

https://doi.org/10.1002/joc.1564

[9] Mourato, S., Moreira, M. and Corte-Real, J. (2010) Interannual Variability of Precipitation Distribution Patterns in Southern Portugal. International Journal of Climatology, 30, 1784-1794. https://doi.org/10.1002/joc.2021

[10] Antunes, S., Pires, O. and Rocha, A. (2006) Detecting Spatio-Temporal Precipitation Variability in Portugal Using Multichannel Singular Spectral Analysis. International Journal of Climatology, 26, 2199-2212. https://doi.org/10.1002/joc.1358

[11] Mesquita, S. and Sousa, A.J. (2009) Bioclimatic Mapping Using Geostatistical Approaches, Application to Mainland Portugal. International Journal of Climatology, 29, 2156-2170. https://doi.org/10.1002/joc.1837

[12] Rodó, X., Baert, E. and Comin, F.A. (1997) Variations in Seasonal Rainfall in Southern Europe during the Present Century, Relationships with the North Atlantic Oscillation and the El Ninõ-Southern Oscillation. Climate Dynamics, 13, 275-284. https://doi.org/10.1007/s003820050165

[13] Rodó, X. (2001) Reversal of Three Global Atmospheric Fields Linking Changes in SST Anomalies in the Pacific, Atlantic, and Indian Oceans at Tropical Latitudes and Midlatitudes. Climate Dynamics, 18, 203-217.

https://doi.org/10.1007/s003820100171

[14] Rodriguez-Puebla, C., Encinas, A.H., Nieto, S. and Garmendia, J. (1998) Spatial and Temporal Patterns of Annual Precipitation Variability over the Iberian Peninsula. The International Journal of Climatology, 18, 299-316. https://doi.org/10.1002/(SICI)1097-0088(19980315)18:3<299::AID-JOC247>3.0.CO; 2-L

[15] Rocha, A. (1999) Low-Frequency Variability of Seasonal Rainfall over the Iberian Peninsula and ENSO. International Journal of Climatology, 19, 889-901. https://doi.org/10.1002/(SICI)1097-0088(19990630)19:8<889::AID-JOC404>3.0.CO;2-P 
[16] Gouveia, C., Trigo, R.M., Da Camara, C.C., Libonati, R. and Pereira, J.M.C. (2008) The North Atlantic Oscillation and European Vegetation Dynamics. International Journal of Climatology, 28, 1835-1847. https://doi.org/10.1002/joc.1682

[17] Della-Marta, P.M., Luterbacher, J., Von Weissenfluh, H., Xoplaki, E., Brunet, M. and Wanner, H. (2007) Summer Heat Waves over Western Europe 1880-2003, Their Relationship to Large-Scale Forcings and Predictability. Climate Dynamics, 29, 251-275. https://doi.org/10.1007/s00382-007-0233-1

[18] García-Herrera, R., Díaz, J., Trigo, R. and Hernández, E. (2005) Extreme Summer Temperatures in Iberia, Health Impacts and Associated Synoptic Conditions. Annales Geophysicae, 23, 239-251. https://doi.org/10.5194/angeo-23-239-2005

[19] Nogueira, P. and Paixão, E. (2008) Models for Mortality Associated with Heatwaves, Update of the Portuguese Heat Health Warning System. International Journal of Climatology, 28, 545-562. https://doi.org/10.1002/joc.1546

[20] Díaz, J., García-Herrera, R., Trigo, R.M., Linares, C., Valente, M.A., De Miguel, J.M. and Hernández, E. (2006) The Impact of the Summer 2003 Heat Wave in Iberia, How Should We Measure It? International Journal of Biometeorology, 50, 159-166. https://doi.org/10.1007/s00484-005-0005-8

[21] Alcoforado, M.-J. and Andrade, H. (2006) Nocturnal Urban Heat Island in Lisbon (Portugal): Main Features and Modeling Attempts. Theoretical Applied Climatology, 84, 151-159. https://doi.org/10.1007/s00704-005-0152-1

[22] Monteiro, A. and Madureira, H. (2009) The Shape and Magnitude of Porto's Heat Island as a Sustainability Indicator. 45 th ISOCARP Congress, Porto, 18-22 October $2009,15$.

[23] Oliveira, C., Santos, P., Nunes, T., Pio, C., Caseiro, A. and Wahlin, P. (2004) Contribuição das emissões rodoviárias na qualidade do ar na cidade do Porto. The proceedings of the 8th Conferencia Nacional do Ambiente, Lisboa, 27-29 October 2004, 12.

[24] Vemado, F. and Pereira Filho, A.J. (2016) Severe Weather Caused by Heat Island and Sea Breeze Effects in the Metropolitan Area of São Paulo, Brazil. Advances in Meteorology, 2016, Article ID: 8364134. https://doi.org/10.1155/2016/8364134

[25] Sousa, F.B.B. and Karam, H.A. (2014) Análise da Estrutura Termodinâmica Associada ao Desenvolvimento de Tempestade Ocorrida entre 17 e 18 de Março de 2013 no Estado do Rio de Janeiro, Brasil. Anuário do Instituto de Geociências (UFR), 37, 17-26. (In Portuguese) https://revistas.ufrj.br/index.php/aigeo/article/view/6971 https://doi.org/10.11137/2014_1_17_26

[26] Marques Filho, E.P., Karam, H.A., Miranda, A.G. and França, J.R.A. (2009) Rio de Janeiro's Tropical Urban Climate. Buletim of the International Association of Urban Climate, 32, 5-9.

[27] Flores Rojas, J.L., Karam, H.A., Marques Filho, E.P. and Pereira Filho, A.J. (2015) Estimation of Atmospheric Turbidity and Surface Radiative Parameters Using Broadband Clear Sky Solar Irradiance Models in Rio de Janeiro-Brasil. Theoretical and Applied Climatology, 1, 1-25.

[28] Pereira Filho, A.J., Carbone, R., Tuttle, J. and Karam, H.A. (2015) Convective Rainfall in Amazonia and Adjacent Tropics. Atmospheric and Climate Sciences, 5, 137-161. https://doi.org/10.4236/acs.2015.52011

[29] Lopez, M.D.C.S., Pereira Filho, A.J. and Pinaya, J.L.D. (2021) Hydrometeorology of Anthropogenic Erosion in the Metropolitan Region of São Paulo. Journal of Environmental Protection, 12, 1234-1253. https://doi.org/10.4236/jep.2021.1212073 
[30] Flores Rojas, J.L., Pereira Filho, J.A., Karam, H.A., Vemado, F. and Masson, V. (2018) Effects of Explicit Urban-Canopy Representation on Local Circulations above a Tropical Mega-City. Boundary-Layer Meteorology, 166, 83-111. https://doi.org/10.1007/s10546-017-0292-8

[31] Cardoso, R.M.M. (2020) Contribuição do Balanço de Energia sobre Superfícies Urbanas no Desenvolvimento de Tempestades na Região Metropolitana do Rio de Janeiro. Master Thesis. Programa de Engenharia Civil, COOPE, Universidade Federal do Rio de Janeiro-UFRJ, Brazil, 88 p.

[32] Stull, R.B. (1988) An Introduction to Boundary-Layer Meteorology. Vol. 13, Springer Science \& Business Media, Berlin. https://doi.org/10.1007/978-94-009-3027-8

[33] Karam, H.A., Pereira Filho, A.J., Masson, V., Noilhan, J. and Marques Filho, E.P. (2010) Formulation of a Tropical Town Energy Budget (t-TEB) Scheme. Theoretical and Applied Climatology, 101, 109-120. https://doi.org/10.1007/s00704-009-0206-X

[34] Pereira Filho, A.J., Pinto, M.A.R., Manfredini, L., Lima, F.A.D., Pinto, A.C., Moribe, C.H., Vemado, F. and Silva Júnior, I.W.D. (2020) CESP Integrated Precipitation Estimation and Forecasting System for Its Watersheds. Revista Brasileira de Meteorologia, 35, 529-552. https://doi.org/10.1590/0102-7786352023

[35] Karam, H.A. (2014) Modelagem da distribuição da saturação de água do solo em terrenos complexos baseada na teoria de similaridade-proposição de abordagem lagrangiana. Anuário do Instituto de Geociências-UFRJ, 37, 139-150. (In Portuguese) https://revistas.ufrj.br/index.php/aigeo/article/view/7829 https://doi.org/10.11137/2014_2_139_150

[36] Karam, H.A., Pereira Filho, A.J. and Flores Rojas, J.L. (2017) On the Precipitation Homogeneity Hypothesis in the TOPMODEL Applications. In Geo-Technologies and Natural Disasters (Special Edition). Brazilian Journal of Cartography, 69, 13-22. https://seer.ufu.br/index.php/revistabrasileiracartografia/article/view/44028

[37] Karam, H.A., Silva, J.C.B., Pereira Filho, A.J. and Flores Rojas, J.L. (2016) Dynamic Modelling of Dengue Epidemics in Function of Available Enthalpy and Rainfall. Open Journal of Epidemiology, 6, 50-79. https://doi.org/10.4236/ojepi.2016.61007

[38] Silva, J.C.B., Karam, H.A. and Machado, C.J.S. (2018) Visualizing Fit between Dengue and Climatic Variables on Capitals of the Brazilian Northeast Region by Generalized Additive Models. Open Journal of Epidemiology, 8, 259-275.

https://doi.org/10.4236/ojepi.2018.84020

[39] Franco dos Santos, S.A. (2019) Variabilidade e previsibilidade interanual da Dengue no município do Rio de Janeiro. Graduation final monograph. In Portuguese. Departamento de Meteorologia, Instituto de Geociências, Universidade Federal do Rio de Janeiro, UFRJ, Brazil.

[40] Balogun, R., Adefisan, E., Adeyewa, Z., Okogbue, E. and Akinbobola, A. (2022) Diurnal Cycle of Rainfall and Convective Properties over West and Central Africa. Atmospheric and Climate Sciences, 12, 74-85.

https://doi.org/10.4236/acs.2022.121006

[41] Bolton, D. (1980) The Computation of Equivalent Potential Temperature. Monthly Weather Review, 108, 1046-1053. https://doi.org/10.1175/1520-0493(1980)108<1046:TCOEPT >2.0.CO;2

[42] Bohren, C.F. and Albrecht, B.A. (1998) Atmospheric Thermodynamics. Oxford Univ. Press, London, 402 p.

[43] Robinson, P. and Sellers-Henderson, A. (1991) Contemporary Climatology. 2nd Edition, Pearson Education, London, 317 p.

[44] Barry, R.G. and Carleton, A.M. (2013) Synoptic and Dynamic Climatology. Rout- 
ledge, London. https://doi.org/10.4324/9780203218181

[45] IPMA (2022) Instituto Português do Mar e da Atmosfera. https://www.ipma.pt/pt/index.html

[46] Thornthwaite, C.W. (1948) An Approach toward a Rational Classification of Climate. Geographical Review, 38, 55-94. https://doi.org/10.2307/210739

[47] Ward, A.D. and Elliot, W.J. (1995) Environmental Hydrology. Lewis Publishers, Boca Raton, $462 \mathrm{p}$.

[48] Wunderground (2014) Automatic Weather Stations Data. https://www.wunderground.com/ 